\title{
The green thorns of Ulex europaeus play both defensive and photosynthetic roles: consequences for predictions of the Enemy Release Hypothesis
}

Silvia Medina-Villar ( $\square$ medina_villar@hotmail.com)

Universidad de La Serena https://orcid.org/0000-0002-4675-7928

Beatriz R. Vázquez de Aldana

Instituto de Recursos Naturales y Agrobiología de Salamanca: Instituto de Recursos Naturales y

Agrobiologia de Salamanca

Asier Herrero Méndez

Universidad del Pais Vasco

M. Esther Pérez-Corona

Universidad Complutense de Madrid

Ernesto Gianoli

Universidad de La Serena

\section{Research Article}

Keywords: cellulose, gorse, physical defenses, plant-herbivory interactions, spines, thorns

Posted Date: May 11th, 2021

DOl: https://doi.org/10.21203/rs.3.rs-436293/v1

License: (c) (1) This work is licensed under a Creative Commons Attribution 4.0 International License.

Read Full License

Version of Record: A version of this preprint was published at Biological Invasions on November 13th, 2021. See the published version at https://doi.org/10.1007/s10530-021-02648-8. 


\section{Abstract}

Ulex europaeus, a thorny shrub native to NW Europe, is one of the worst invasive species worldwide. The mechanisms underlying its invasive success are not completely understood. According to the Enemy Release Hypothesis (ERH), lower pressure by vertebrate herbivores in the invaded areas should lead to lower investment in physical defenses, allowing the plant to invest more in growth and/or reproduction. However, antiherbivore physical defenses in $U$. europaeus (thorns) are also the main photosynthetic tissue of the plant. Therefore, reduced investment in thorns could compromise growth of Ulex europaeus in the invaded range. We hypothesized that changes in physical defenses of $U$. europaeus in invaded ranges should reflect reduced effectiveness (e.g., softer, and more palatable tissues) but not reduced biomass allocation. We compared $U$. europaeus plants from the invaded (Chile) and native (Spain) ranges of distribution regarding: i) spinescence traits (thorn length, width, biomass, slenderness and bending strength) in adult plants, ii) thorn fiber content and digestibility (as proxies for palatability) in adult plants, and iii) spine density in seedlings grown in a common garden. As expected, plants in the invaded range invested more mass in larger thorns, which contained less cellulose, were slenderer and easier to bend than those from plants in the native range. Likewise, seedlings from the invaded range showed lower spine density and more diameter growth, thus supporting the ERH. Our study shows functional changes in spinescence traits between distribution ranges that account for the fact that thorns are both defensive and photosynthetic organs in $U$. europaeus, and these changes may contribute to explain its invasiveness.

\section{Introduction}

A major goal of invasion ecology is to understand why some exotic species are successful invaders (Catford et al. 2009), and to this end studies comparing native and invaded distribution ranges are especially relevant (Hierro et al. 2005; Cronin et al. 2015). The enemy release hypothesis (ERH) is one of the main hypotheses with a biogeographical approach to explain the success of exotic invasive plant species (invasive plants, hereafter) (Keane and Crawley 2002; Colautti et al. 2004; Jeschke et al. 2012). This hypothesis posits that the reduced abundance or absence of natural enemies in the colonized range may allow the invasive plants to invest more in growth and/or reproduction and less in defense (Blossey and Notzold 1995; Keane and Crawley 2002; Colautti et al. 2004) thus adjusting their plant fitness in the new environment. Several studies, particularly evaluating chemical defenses, have verified the predictions of the ERH (e.g., Joshi and Vrieling 2005; Liu and Stilling 2006; Hull-Sanders et al. 2007; Gruntman et al. 2017), but few studies have evidenced shifts toward both lower defense and higher growth in introduced populations (Bossdorf et al. 2005).

Plant physical or structural defenses (e.g., spinescence, pubescence, sclerophylly) respond to vertebrate herbivory pressure (Obeso 1997; Hanley et al. 2007; Gómez and Zamora 2002; Musariri et al. 2018). Spinescence, a term including sharp-pointed modifications of leaf parts (spines), stems or branches (thorns) and epidermal outgrowths (prickles), is an effective physical defense against vertebrate herbivores (Cooper and Owen-Smith 1986; Cooper and Ginnett 1998; Milewski et al. 1991; Hanley et al. 
2007; Wigley et al. 2019). Sclerophylly (hardened leaves) is a wide-spectrum defensive trait, decreasing the palatability and digestibility of plant tissues through a high content of digestibility-reducing compounds, such as lignin or cellulose fibers, and a low nutrient content (Lundberg and Åström 1990; Turner 1994; Hanley et al. 2007). A cafeteria experiment showed that sheep and goat preferences were positively associated with plant digestibility and feeding preferences of white-tailed deer (Odocoileus virginianus) negatively correlated with plant fiber content (Lambert et al.1989; Dostaler et al. 2011). Some mechanical properties related to sclerophylly, e.g., flexural stiffness and fracture toughness, are predictors of resistance to herbivores (Choong et al. 1992; Lucas et al. 2000; Hanley et al. 2007; Guerra et al. 2010). Simulated trampling damage increased stem resistance to bending and rupture in shrub species (Xu et al. 2013). Plant physical defenses may change with plant ontogeny: due to limitations on resource acquisition, seedlings often show less investment in physical defenses than mature plants (Boege and Marquis 2005; Hanley et al. 2007; Mediavilla et al. 2018; but see Clark and Burns 2015). Nonetheless, physical defenses in seedlings are effective against vertebrate and invertebrate herbivores but costly (Cooper and Ginnett 1998; Boege and Marquis 2005; Cash and Fulbright 2005; Barton and Hanley 2013).

In line with the $E R H$, a meta-analysis reported that invasive plants in the invaded range generally show lower investment in digestibility-reducing compounds, such as tannins and lignin, compared to the native range (Zhang et al. 2018). Besides, plants of Arctotheca populifolia from the invaded range were less tough than those from the native range (Brandenburguer et al. 2019). Yet, spinescence traits, such as thorns and spines, have not been compared between invaded and native ranges in any plant invader, to the best of our knowledge. Invasive thorny plants, originally well-armed against vertebrate herbivores, are good models to test predictions of the ERH.

Ulex europaeus L. (Fabaceae), a thorny shrub native to NW Europe, is considered among the world's worst invasive species (Lowe et al. 2000; Clements et al. 2001). Once established in the introduced ecosystems, through mechanisms not completely understood, $U$. europaeus dramatically increases in size and abundance, creating thick monocultures (Muñóz 2009). Some characteristics that may favor its invasiveness are high growth rate, strong ability to resprout, high seed output, persistent seed bank and considerable evolutionary potential (Atlan et al. 2015; Hornoy et al. 2013; Reyes et al. 2009). In a common garden experiment, $U$. europaeus seedlings from the invaded range were taller than plants from the native range but had similar insect infestation rates and similar concentrations of defensive alkaloids (Hornoy et al. 2011; Hornoy et al. 2012). Because these studies did not consider physical defenses, it remains an open question whether changes in physical defenses could be associated with the increased growth of $U$. europaeus in the invaded range. In this study we aimed to answer this question.

In the native range, $U$. europaeus is consumed by wild vertebrate herbivores, such as red deer (Cervus elaphus L.), roe deer (Capreolus capreolus L.) and rabbit (Oryctolagus cuniculus L.) (González-Hernandez and Silva-Pando 1996, 1999; Alves et al. 2006), and by domestic ungulates, such as goats, sheep, cows, and horses (Putman et al. 1987; Howe et al. 1988; Clements et al. 2001; Atlan et al. 2015). In contrast, some invaded areas, as is the case of Chile, lack native big vertebrate herbivores (Jaksic 2001). Also, in Chile, exotic vertebrate herbivores possibly coexisting with $U$. europaeus in the native range were 
introduced at least 50 years after U. europaeus (Jaksic 1998). The introduced vertebrate herbivores, such as wild rabbits and domestic ungulates, often prefer native over exotic plant species, thus favoring invasion by exotic plant species (Jaksic 1998; Holmgren et al. 2000; Holmgren 2002; Jaksic et al. 2002; Vázquez 2002; Mitchell et al. 2006; Parker et al. 2006; Oduor et al. 2010). In the invaded range, $U$. europaeus is not commonly used as fodder species for domestic ungulates, as is the case in the native range (Atlan et al. 2015; Dietl et al. 2009). Therefore, U. europaeus likely faces lower pressure by vertebrate herbivores in the invaded range. According to the ERH, the lower herbivory pressure in the invaded range compared to the native range should lead to lower investment in physical defenses and/or increased growth in invasive populations of $U$. europaeus, but this specific hypothesis has not been experimentally tested.

Concerning the evaluation of the ERH predictions, U. europaeus has a particularly interesting biological feature: since leaves in mature plants are reduced to spine-like phyllodes, the green thorns (together with the green branches) are at the same time physical defenses and the main photosynthetic tissue (in terms of mass and surface); (Clements et al. 2001; Cubas 2008). Therefore, the ERH-predicted that a reduction in physical defenses in the invaded range should not be the result of less biomass allocation to thorns, which could hinder plant growth. Instead, structural changes associated with a reduced effectiveness of physical defenses, together with increased growth, should be expected.

In the present study we compared physical defenses between $U$. europaeus populations in the native (Spain) and invaded (Chile) distribution ranges. In adult plants collected from natural field populations, we measured spinescence traits, thorn allocation parameters and thorn bending strength, as well as fiber content and digestibility of thorns (as proxies for palatability). In addition, we measured spine density and growth in seedlings from both origins grown in a common garden. We expected to find i) spinescence traits associated with reduced effectiveness of antiherbivore defenses, ii) higher palatability, and iii) higher seedling growth in the invaded range compared to the native range.

\section{Materials And Methods}

\section{Study species}

Ulex europaeus (gorse) is a shrub that can be $2.5 \mathrm{~m}$ tall in the native range of distribution, but it can reach over $5 \mathrm{~m}$ in the invaded range (Clements et al. 2001; Cubas 2008 Barrera-Cataño et al. 2019). It has two types of branches, one of limited growth that lignifies fast and another of prolonged growth that develops when conditions are favorable and lignifies the next year. The latter type is softer and more flexible. Young plants develop alternate petiolate leaves with 1-3 leaflets, while leaves in the adult plants are modified and reduced to triangular rigid spiny phyllodes $(5-12 \mathrm{~mm})$. Therefore, green branches and stems are the main photosynthetic tissues in adult plants. Branches have a spiny end, and each branch develops sharp-pointed stems (primary thorns), which in turn develop secondary and tertiary thorns. Each thorn has a phyllode in its base (Cubas 2008). 
Domestic animals (e.g., sheep and goat) can ingest different parts of $U$. europaeus, including green and lignified thorns, new vegetative buds, barks, and flowers (Atlan et al. 2015; Radcliffe 1986). However, though $U$. europaeus was introduced worldwide as forage, ornamental or hedge plant in the 1800 s and 1900s, this species is not considered a fodder species and neither used as fodder in the invaded range, which, together with the absence of management practices, may have favored its expansion (Atlan et al. 2015). In Chile, it was first cited in 1847 , being now spread from $33^{\circ} \mathrm{S}$ to $41^{\circ} \mathrm{S}$, reaching high densities and large sizes, and even invading areas of conservation value (Clements et al. 2001; Muñóz 2009; Fuentes et al. 2014; Altamirano et al. 2016).

\section{Plant material collection}

The collection of branches, thorns and seeds was done during spring 2018 in three $U$. europaeus populations with similar climatic conditions within the native (Pontevedra, Spain) and invaded (Concepción, Chile) ranges (Fig. 1, Online resource 1). Climatic data for the period 1982-2012 were obtained from https://es.climate-data.org. The minimum distance between individuals in each of the six populations sampled was $1 \mathrm{~m}$. Populations in native and invaded ranges showed little browsing damage when the sampling was carried out (S. Medina-Villar, personal observation). Populations in Spain showed little herbivory likely because the sites were located close to roads and urban areas, which could limit the access of wild mammal herbivores. Nonetheless, these populations certainly had a longer evolutionary history of herbivory than their Chilean counterparts. Populations in Chile were also located close to roads. To measure spinescence traits and fiber content in adult individuals, a total of 60 branches ( 1 branch $\times 10$ individuals $\times 3$ populations $\times 2$ distribution ranges) were collected. Besides, a pool of seeds (ca. $25 \mathrm{~g}$ of seeds, ca. 5190 seeds) from 30 individuals were collected in each site, Pontevedra and Concepción.

\section{Spinescence traits}

Branches collected in the field were oven-dried at $60^{\circ} \mathrm{C}$ for at least $48 \mathrm{~h}$ befre measure spinescence traits. Measurements were made in green thorns, avoiding senesced parts. Thorn length $(L)$ and thorn-base width perpendicular to the branch (W) were measured in a total of 1200 primary thorns (20 thorns $x 1$ branch $\times 10$ individuals $\times 3$ populations $\times 2$ distribution ranges) using a digital caliper (Figs 2A, B). Thorn length was measured from the base of the thorn to its tip (Figs 2A, B). In other Fabaceae species thorn length has been shown to increase in response to herbivory (Young et al. 2003; Wigley et al. 2019). Thorn width can be used to estimate defense effectiveness against herbivores (Pérez-Harguindeguy et al. 2013). the L:W ratio was calculated, which is analogous to the slenderness ratio (height:diameter; the inverse of sturdiness) commonly measured in plants (Haase 2008; Valladares et al. 2012).

In each branch, four branch segments were randomly subsampled and cut to calculate thorn density (number of thorns per $\mathrm{cm}$ of branch segment) and biomass allocation to thorns, i.e., the ratio between the thorn dry weight and the branch segment dry weight (480 branch segments in total $=4$ branch segments $\mathrm{x} 2$ branches $\mathrm{x} 10$ individuals $\mathrm{x} 3$ populations $\mathrm{x} 2$ distribution ranges). Previous studies in other shrub species have reported a positive correlation between spine density and herbivory pressure (Musariri et al. 
2018; Cavagnaro et al. 2017). All the above-mentioned variables were averaged by individual (10 per population). To standardize measurements, all the spinescence traits were divided by branch length.

\section{Bending strength of thorns}

In freshly collected primary thorns, flexural stiffness (elastic resistance to bending) was estimated by the following formula: $(F / D) \times B^{3}$, where $F$ is the force, $D$ is the displacement and $B$ is the span length between supports in the bending test (Hanley et al. 2007). We kept parameters $B$ and $D$ constant and estimated $F$ in a total of 144 thorns ( 6 thorns $\times 4$ randomly selected individuals $\times 3$ populations $\times 2$ distribution ranges). Using a vise, thorns were fixed at $3 \mathrm{~cm}$ from the thorn tip by pressing the side (width) of the thorn that is perpendicular to the branch. At $1 \mathrm{~cm}$ from the thorn tip, a plastic container was hanged - using a thread as handle- and increasing weight was applied to the container (by adding rice) until the thorn bent at a $10^{\circ}$ angle. Therefore, $B$ was $2 \mathrm{~cm}, D$ was $10^{\circ}$ angle and $F$ was the weight necessary to bend a thorn $10^{\circ}$, which we termed bending strength (Van Gelder et al. 2006; Shah et al. 2017). A scheme of the bending test performed is shown in Figure $2 \mathrm{C}$. The total length of each thorn submitted to the bending test was also recorded because thorn size may influence its bending strength (Van Gelder et al. 2006).

\section{Fiber content of thorns}

To analyze fiber content, individual thorn samples from each population were pooled and then were dried and pulverized with a mixer mill (Retsch MM 301). In a total of 24 samples (4 pooled samples $x 3$ populations $x 2$ distribution ranges) were analyzed for neutral detergent fiber (NDF), acid detergent fiber (ADF), lignin, cellulose, and dry matter digestibility (DMD) using the filter bag technique, in an Ankom Automated Fiber Analyzer A2000 (Ankom, USA), based on the analytical method of Göering and Van Soest (1970).

\section{Common garden experiment}

In June 2019 air-dried seeds of U. europaeus from Concepción (Chile) and Pontevedra (Spain) were sown in square pots $(11 \times 11 \times 12 \mathrm{~cm})$ containing a 90:10 (v/v) mixture of organic substrate (50:50 white peat moss and black peat; Projar Professional Seed Pro 5050;) and vermiculite. Due to seed coat hardiness, seeds were pretreated at $80^{\circ} \mathrm{C}$ for 30 min to ensure germination success. A total of 120 seedlings per distribution range grew for six months in the pots in common environmental conditions (minimum temperature $18{ }^{\circ} \mathrm{C}$, maximum temperature $25^{\circ} \mathrm{C}$, watered when needed) in a greenhouse at the Alfonso XIII Botanical Garden (Complutense University of Madrid, Spain). We considered the six-month plants as seedlings because most of them still had their cotyledons. In each seedling the following parameters were measured: the stem diameter below cotyledon insertion, plant height and spine density, which was visually estimated as the percentage of plant height that developed spines. Note that seedlings do not develop thorns, but they do show leaves and spines (i.e., sharp-pointed modified leaves). Figure 3 shows seedlings of $U$. europaeus from Spain and Chile. 
Linear Mixed Models (LMM) were performed to assess differences in standardized spinescence variables ( $L, W, L: W$, density and biomass), fiber contents and DMD between distribution ranges (invaded vs. native range; fixed factor), using population as random factor to account for population variability. To evaluate the relationships between spinescence variables and branch length in $U$. europaeus from each range, LMM were performed using distribution range as fixed factor, branch length as covariate and population as random factor. Principal Component Analyses were performed to visualize relationships among fiberrelated variables (lignin, cellulose, ADF, NDF and DMD) and among spinescence variables in U. europaeus thorns from native and invaded ranges. Permutational multivariate analysis of variance (PERMANOVA) was used to assess differences between distribution ranges considering all fiber-related variables on one hand, and all spinescence variables on the other hand. To evaluate the effect of distribution range (fixed factor) on the bending strength of thorns (dependent variable), a LMM was performed using $L$ as covariate and population as random factor.

A one-way ANOVA was used to compare the diameter and height of seedlings between distribution ranges (fixed factor). To deal with excess of zeros in spine density of seedlings (dependent variable), we performed a Generalized Linear Model (GLM, family quasibinomial) with distribution range as fixed factor (Zuur et al. 2009). When needed, dependent variables were transformed with log, root-square or power functions to meet homocedasticity and normality in LMMs and ANOVA. Statistical analyses were performed in R software 3.4.3 (R Core Team 2017) using "Imer" function (Ime4 package) for LMM, "adonis2" function (vegan package) for PERMANOVA, the built-in R function "prcomp" for PCA, and "glm" function for GLM (Bates et al. 2015; Zeileis et al. 2008; Jari et al. 2020).

\section{Results}

Overall, spinescence traits in $U$. europaeus plants from the invaded range differed from those of the native range (PERMANOVA, pseudo- $F_{1}=30.6, P<0.001 ; \mathrm{PCA}$ in Online Resource 2 ). The effect of distribution range was significant for all the spinescence traits except for thorn density (LMM, Table 1). Specifically, thorn length (L), thorn width (W), L:W, and thorn biomass allocation were greater in the invaded range than in the native (Fig. 4).

Thorn length and $\mathrm{L}: \mathrm{W}$ were greater in the invaded range and increased with branch length in both the native and the invaded ranges (Table 2; Fig. 5). Thorn density did not differ between plants from Chile and Spain, decreased with increasing branch length in both distribution ranges, but the slope was greater in plants from the invaded range (Table 2; Fig. 5). In the case of thorn biomass allocation, it was, overall, greater in the invaded range, decreased with increasing branch length in the invaded range and did not vary with branch length in the native range (Table 2; Fig. 5). Importantly, thorns from the native range showed a greater length-corrected bending strength than thorns from the invaded range, being this difference minimized in the longest thorns (Range, $\mathrm{F}_{1}=9.1, P=0.0035$; Thorn length, $\mathrm{F}_{1}=7.2, P=0.0084$; Range $x$ Thorn length, $\mathrm{F}_{1}=6.0, P=0.0156$, Fig. 6) . 
Overall, $U$. europaeus plants from the invaded range differed from those of the native range in fiberrelated traits (PERMANOVA, $\mathrm{F}=10.9, P<0.001$; PCA in Online Resource 3 ). Fiber contents of thorns tended to be greater in the native range, the differences being significant for NDF and cellulose, marginally significant for ADF and non-significant for lignin (Table 3). Our estimate of digestibility (DMD) tended to be lower in thorns from the native range, but differences were not significant (Table 3 ).

Seedlings of $U$. europaeus from the native range showed higher spine density than seedlings from the invaded range ( $\mathrm{t}=5.5, P<0.001, \mathrm{GLM}$; Fig. 7$)$. Interestingly, whereas 6 -month seedlings did not differ in height $\left(F_{1}=0.11, P=0.7369\right.$, ANOVA; Fig. 7$)$, those from the invaded range showed thicker stems $\left(F_{1}=\right.$ $4.5, P=0.0357$, ANOVA; Fig. 7), which indicates greater biomass production.

\section{Discussion}

Our results show that in the invaded range adult plants of $U$. europaeus shift towards increasing photosynthetic tissue (thorn size and biomass) and decreasing thorn effectiveness against herbivores: less fibrous, slenderer and easier to bend thorns. Plant stems may have different functions, which may conflict structural and functional requirements (Speck and Burgert 2011). In the case of adult plants of $U$. europaeus, stems are at the same time physical anti-herbivore defenses, thorns, and the main photosynthetic tissue, as leaves are reduced to small triangular squamous phyllodes (Cubas 2008). This particular feature of $U$. europaeus somewhat challenges the predictions of the Enemy Release Hypothesis (ERH) (Keane and Crawley 2002; Colautti et al. 2004). Thus, a lower herbivory pressure in the invaded range would not lead to a lower investment in thorn size or biomass because it could reduce interception of photosynthetically active radiation and hence decrease plant growth. Nonetheless, consistent with the fundamental tenets of ERH, the changes in structural design, fiber composition, biomass allocation and strength in $U$. europaeus thorns in the invaded range resulted in these physical defenses being less efficient against vertebrate herbivores (Lambert et al. 1989; Read and Stokes 2006; Xu et al. 2013).

All the morphological, compositional and mechanical changes observed in U. europaeus thorns in the invaded range may favor the success of this invasive shrub. For instance, increased size and biomass of the main photosynthetic tissue (green thorns) in the invaded range may favor plant growth because the photosynthetic area (usually leaf area) is a main driver of light interception and ultimately plant productivity (Gifford et al. 1984; Koester et al. 2014; Weraduwage et al. 2015). Moreover, a lower investment in costly fibers, such as cellulose (Poorter and De Jong 1999), in the invaded range leaves more resources available to invest in other plant functions that contribute to vital rates. In line with our results, an experimental study with an evergreen tree species and a meta-analysis showed that the content of digestibility-reducing compounds was lower in plants from the invaded range compared to those from the native range (Montti et al. 2016, Zhang et al. 2018).

The lower bending strength of thorns in the invaded range compared to the native range, a key result concerning physical defense effectiveness, was likely associated with differences in the content of structural compounds (cellulose) and patterns of biomass allocation, resulting in less fibrous and 
slenderer thorns. We emphasize that, to our knowledge, the reduction in bending strength of a physical defense in the invaded range has not been documented in the literature for any invasive plant species. This is rather surprising, given the relevance of physical defenses, such as spinescence traits, for plant protection against vertebrate herbivores (Obeso 1997; Gómez and Zamora et al. 2002; Hanley et al. 2007). It is much more common to find results linked to leaf toughness, which is generally lower in the invaded range (Agrawal et al. 2005; Liao et al. 2013; but see: Ridenour et al. 2008; Franks et al. 2008). We hypothesize that the reduction in bending strength in $U$. europaeus may be a consequence of the lower selective pressure exerted by herbivores in the invaded range (Jacksic 1998, 2001; Atlan et al. 2015). However, the specific mechanical properties of physical defenses that deter vertebrate herbivores are not completely understood (Read and Stokes 2006; Sanson 2006).

Unlike adult plants, seedlings of $U$. europaeus do not develop thorns, but they do show leaves and spines. Therefore, seedlings are amenable to "traditional" tests of the ERH. We found a negative relationship between physical defense (spine density) and growth (in diameter) in U. europaeus seedlings, with more investment in growth and less in defense in the invaded range, as predicted by the ERH. This shift in resource allocation between defense and growth was not found in earlier studies addressing the relationship between chemical defenses and growth in $U$. europaeus (Hornoy et al. 2011, 2012). In fact, few studies reported both ERH-predictions, decreased defense and increased growth, in the same invasive species (Bossdorf et al. 2005). Seedlings are generally considered to rely more on chemical than on physical defenses against herbivores (Barton and Hanley 2013). However, our results suggest that physical defenses may be relevant during the early establishment of $U$. europaeus. Seedlings are commonly highly susceptible to big vertebrate herbivores, such as ungulates, which can easily kill the whole seedling (Rafferty et al. 2005). Nevertheless, spiny seedlings from different species have been shown to effectively deter other herbivores, such as lagomorphs, rodents and invertebrates (Cooper and Ginnett 1998; Boege and Marquis 2005; Cash and Fulbright 2005; Kariyat et al. 2017). Thus, the lower spine density of $U$. europaeus seedlings in the invaded range could result from the release of a variety of herbivores, not only big vertebrate herbivores, which prefer to feed on adult than young plants (Boege and Marquis 2005).

From an applied perspective, the results of this study suggest that land managers can take advantage of the high palatability and reduced effectiveness of physical defenses in plants of $U$. europaeus in Chile to use domestic animals, especially goats, as a measure to control this invasive shrub. The use of goats after plant cutting to control $U$. europaeus is an effective management practice that has been widely used in New Zealand (Howe et al. 1988; Radcliffe 1985, 1986; Popay and Field, 1996). On the other hand, a high invasive potential could be expected for other Fabaceae species with photosynthetic thorns, such as Ulex galli Planch., U. minor Roth. (Stokes et al. 2003) and Prosopis kuntzei Harms. (Böcher 1977), because they could also be partially released from the growth-defense dilemma in the introduced ecosystems.

\section{Conclusions}


This study evidence the role of spinescence traits in the invasiveness of an aggressive and successful thorny shrub, $U$. europaeus. In particular, it shows that in the invaded range (Chile) adult plants of $U$. europaeus shift resource allocation, increasing the amount of photosynthetic tissue (thorn size and biomass) and decreasing thorn effectiveness against herbivores by producing less fibrous, slenderer and easier to bend thorns. In early stages of establishment (seedling stage), lower investment in spines and more in growth in the invaded range may explain the invasion success of $U$. europaeus, according to the $\mathrm{ERH}$. As far as we know, this is the first report of such modification in thorns or spines of a woody species between invaded and native ranges. Whereas higher investment in growth in the invaded range (larger thorns) may provide competitive advantages over native plants, higher investment in defense in the native range (stronger, more fibrous, and robust thorns) may better protect $U$. europaeus against high herbivory pressure. The present study illustrates the need of refinement of ERH predictions to consider additional functions of plant antiherbivore defenses, such as photosynthesis in the case of $U$. europaeus thorns.

\section{Declarations}

All funding (information that explains whether and by whom the research was supported) has been included

No Conflicts of interest/Competing interests

Availability of data and material (data transparency): Not applicable

Code availability (software application or custom code): Not applicable

Additional declarations for articles in life science journals that report the results of studies involving humans and/or animals: Not applicable

Ethics approval (include appropriate approvals or waivers): Not applicable

All authors consent to participate and publish this study

\section{Acknowledgements}

This work and SMV was funded by the project FONDECYT-CONICYT No 3180289 (Chile). BRVA acknowledge funding from project "CLU-2019-05 - IRNASA/CSIC Unit of Excellence", funded by the Junta de Castilla y León and co-financed by the European Union (ERDF "Europe drives our growth"). AH was supported by the University of Alcalás Own Research Programme's 2019/20 Postdoctoral Grant and Basque Country Government funding support to FisioClima $\mathrm{CO}_{2}$ (IT1022-16) research group. EPC acknowledge REMEDINAL3-CM S2013/MAE-2719 network (Comunidad de Madrid) and the funding of UCM Research Group Program (2018, 2020, Research group 91034. Plant Evolutionary Ecology and Restoration Ecology). EG acknowledge funding from the project FONDECYT-CONICYT No 1180334. We 
thank to Marina Briones Rizo and Antonio Requena Serrano for their help during sampling processing and to Carlos Silva for his help with maps.

\section{References}

Agrawal AA, Fishbein M (2006) Plant defense syndromes. Ecology 87:132-149. doi: 10.1890/00129658(2006)87[132:pds]2.0.co;2

Altamirano A, Cely JP, Etter A, et al (2016) The invasive species Ulex europaeus (Fabaceae) shows high dynamism in a fragmented landscape of south-central Chile. Environ Monit Assess 188:495. doi: $10.1007 / \mathrm{s} 10661-016-5498-6$

Alves JAB, Vingada J, Rodrigues P (2006) The wild rabbit (Oryctolagus cuniculus L.) diet on a sand dune area in central Portugal: a contribution towards management. Wildl Biol Pract 2:63-71. doi: $10.2461 /$ wbp.2006.2.8

Atlan A, Udo N, Hornoy B, Darrot C (2015) Evolution of the uses of Gorse in native and invaded regions: what are the impacts on its dynamics and management? Rev D Ecol Terre La Vie 70:191-206

Barrera-Cataño JI, Rojas-Rojas JE, Contreras-Rodríguez SM, Basto-Mercado SI (2019) Plan de prevención, manejo y control de retamo espinoso (Ulex europaeus) y retamo liso (Genista monspessulana) en la jurisdicción CAR. Proceditor Ltda, Bogotá, Argentina

Barton KE, Hanley ME (2013) Seedling-herbivore interactions: Insights into plant defence and regeneration patterns. Ann Bot 112:643-650. doi: 10.1093/aob/mct139

Bates D, Maechler M, Bolker B, Walker S (2015) Fitting linear mixed-effects models using Ime4. J of Statist Soft, 67:1-48. doi:10.18637/jss.v067.i01.

Blossey B, Notzold R (1995) Evolution of increased competitive ability in invasive nonindigenous plants: A hypothesis. J Ecol 83:887. doi: 10.2307/2261425

Böcher TW (1977) Convergence as an evolutionary process. Bot J Linn Soc, 75:1-19.

Boege K, Marquis RJ (2005) Facing herbivory as you grow up: The ontogeny of resistance in plants. Trends Ecol Evol 20:441-448. doi: 10.1016/j.tree.2005.05.001

Bossdorf O, Auge H, Lafuma L, et al (2005) Phenotypic and genetic differentiation between native and introduced plant populations. Oecologia 144:1-11. doi: 10.1007/s00442-005-0070-z

Brandenburger CR, Kim M, Slavich E, et al (2020) Evolution of defense and herbivory in introduced plants -Testing enemy release using a known source population, herbivore trials, and time since introduction. Ecol Evol 10:5451-5463. doi: 10.1002/ece3.6288 
Cash VW, Fulbright TE (2005) Nutrient enrichment, tannins, and thorns: effects on browsing of shrub seedlings. J Wildl Manage 69:782-793. doi: 10.2193/0022-541x(2005)069[0782:netate]2.0.co;2

Catford JA, Jansson R, Nilsson C (2009) Reducing redundancy in invasion ecology by integrating hypotheses into a single theoretical framework. Divers Distrib 15:22-40. doi: 10.1111/j.14724642.2008.00521.x

Cavagnaro FP, Golluscio RA (2017) Structural anti-herbivore defense reduction of two Patagonian spiny shrubs in response to long time exclusion of large herbivores. J Arid Environ 142:36-40. doi: 10.1016/j.jaridenv.2017.03.007

Choong MF, Lucas PW, Ong JSY, et al (1992) Leaf fracture toughness and sclerophylly: their correlations and ecological implications. New Phytol 121:597-610. doi: 10.1111/j.1469-8137.1992.tb01131.x

Clark LL, and Burns KC (2015) The ontogeny of leaf spines: Progressive versus retrogressive heteroblasty in two New Zealand plant species. New Zeal J Bot 53:15-23.

Clements DR, Peterson DJ, Prasad R (2001) The biology of Canadian weeds. 112. Ulex europaeus L. Can J Plant Sci 81:325-337. doi: 10.4141/P99-128

Colautti RI, Ricciardi A, Grigorovich IA, Maclsaac HJ (2004) Is invasion success explained by the enemy release hypothesis? Ecol Lett 7:721-733. doi: 10.1111/j.1461-0248.2004.00616.x

Cooper SM, Ginnett TF (1998) Spines protect plants against browsing by small climbing mammals. Oecologia 113:219-221. doi: 10.1007/s004420050371

Cooper SM, Owen-Smith N (1986) Effects of plant spinescence on large mammalian herbivores. Oecologia 68:446-455. doi: 10.1007/BF01036753

Cronin JT, Bhattarai GP, Allen WJ, Meyerson LA (2015) Biogeography of a plant invasion: Plant-herbivore interactions. Ecology 96:1115-1127. doi: 10.1890/14-1091.1

Cubas P (2008) Ulex L. In Castroviejo S, Aedo C, Laínz M, Muñoz Garmendia F, Nieto Feliner G, Paiva J, Benedí C (eds.). Flora Iberica 8: 149-152. Real Jardín Botánico, CSIC, Madrid. http://www.floraiberica.org/ [accessed 30 September 2020]

Dietl W, Fernández F, Venegas C (2009) Manejo sostenible de praderas. Su flora y vegetación. Boletín INIA $N^{\circ}$ 187. 188p. Oficina de Estudios y Políticas Agrarias (ODEPA) del Ministerio de Agricultura, Chile.

Dostaler S, Ouellet J-P, Therrien J-F, Côté SD (2011) Are feeding preferences of white-tailed deer related to plant constituents? J Wildl Manage 75:913-918. doi: 10.1002/jwmg.118

Franks SJ, Pratt PD, Dray FA, Simms EL (2008) No evolution of increased competitive ability or decreased allocation to defense in Melaleuca quinquenervia since release from natural enemies. Biol Invasions 
Fuentes N, Sánchez P, Pauchard A, Urrutia J, Cavieres L, Marticorena A (2014) Plantas invasoras del centro-sur de Chle: una guía de campo. Laboratorio de Invasiones Biológicas. Concepción, Chile.

Gifford RM, Thorne JH, Hitz WD, Giaquinta RT (1984) Crop productivity and photoassimilate partitioning. Science 225:801-808. doi: 10.1126/science.225.4664.801

Göering HK, Van Soest PJ (1970) Forage fiber analyses (Apparatus, Reagents, Procedures, and Some Applications). Agricultural Handbook No.379, Agr. Res. Serv., USDA, p. 1-19.

Gómez JM, Zamora R (2002) Thorns as induced mechanical defense in a long-lived shrub (Hormathophylla spinosa, Cruciferae). Ecology 83:885-890. doi: 10.1890/00129658(2002)083[0885:TAIMDI]2.0.C0;2

González Hernández MP, Silva-Pando FJ (1996) Grazing effects of ungulates in a Galician oak forest (northwest Spain). For Ecol Manage 88:65-70. doi: 10.1016/S0378-1127(96)03810-8

González-Hernández MP, Silva-Pando FJ (1999) Nutritional attributes of understory plants known as components of deer diets. J Range Manag 52:132-138. doi: 10.2307/4003506

Gruntman M, Segev U, Glauser G, Tielbörger K (2017) Evolution of plant defences along an invasion chronosequence: defence is lost due to enemy release - but not forever. J Ecol 105:255-264. doi: $10.1111 / 1365-2745.12660$

Guerra PC, Becerra J, Gianoli E. 2010. Explaining differential herbivory in sun and shade: the case of Aristotelia chilensis saplings. Arthropod-Plant Interact 4:229-235.

Haase DL (2008) Understanding forest seedling quality: measurements and interpretation. Tree Plant Notes $52: 24-30$

Hanley ME, Lamont BB, Fairbanks MM, Rafferty CM (2007) Plant structural traits and their role in antiherbivore defence. Perspect Plant Ecol Evol Syst 8:157-178. doi: 10.1016/j.ppees.2007.01.001

Hierro JL, Maron JL, Callaway RM (2005) A biogeographical approach to plant invasions: The importance of studying exotics in their introduced and native range. $J$ Ecol 93:5-15. doi: 10.1111/j.13652745.2004.00953.x

Holmgren M (2002) Exotic herbivores as drivers of plant invasion and switch to ecosystem alternative states. Biol Invasions 4:25-33. doi: 10.1023/A:1020535628776

Holmgren M, Avilés R, Sierralta L, et al (2000) Why have European herbs so successfully invaded the Chilean matorral? Effects of herbivory, soil nutrients, and fire. J Arid Environ 44:197-211. doi:

10.1006/jare.1999.0589 
Hornoy B, Atlan A, Roussel V, Buckley YM, Tarayre M (2013) Two colonisation stages generate two different patterns of genetic diversity within native and invasive ranges of Ulex europaeus. Heredity (Edinb) 111:355-63. doi: 10.1038/hdy.2013.53

Hornoy B, Atlan A, Tarayre M, et al (2012) Alkaloid concentration of the invasive plant species Ulex europaeus in relation to geographic origin and herbivory. Naturwissenschaften 99:883-892. doi: $10.1007 / \mathrm{s} 00114-012-0970-9$

Hornoy B, Tarayre M, Hervé M, et al (2011) Invasive plants and enemy release: Evolution of trait means and trait correlations in Ulex europaeus. PLoS One 6:1-10. doi: 10.1371/journal.pone.0026275

Howe JC, Barry TN, Popay Al (1988) Voluntary intake and digestion of gorse (Ulex europaeus) by goats and sheep. J Agric Sci 111:107-114. doi: 10.1017/S0021859600082885

Hull-Sanders HM, Clare R, Johnson RH, Meyer GA (2007) Evaluation of the evolution of increased competitive ability (EICA) hypothesis: Loss of defense against generalist but not specialist herbivores. J Chem Ecol 33:781-799. doi: 10.1007/s10886-007-9252-y

Jaksic FM (1998) Vertebrate invaders and their ecological impacts in Chile. Biodivers Conserv 7:14271445. doi: 10.1023/A:1008825802448

Jaksic FM (2001) Spatiotemporal variation patterns of plants and animals in San Carlos de Apoquindo, central Chile. Rev Chil Hist Nat 74:477-502. doi: 10.4067/S0716-078X2001000200021

Jaksic FM, Iriarte JA, Jiménez JE, Martínez DR (2002) Invaders without frontiers: Cross-border invasions of exotic mammals. Biol Invasions 4:157-173. doi: 10.1023/A:1020576709964

Jari Oksanen, F. Guillaume, Blanchet, Michael Friendly, Roeland Kindt, Pierre Legendre, Dan McGlinn, Peter R. Minchin, R. B. O'Hara, Gavin L. Simpson, Peter Solymos, M. Henry H. Stevens, Eduard Szoecs and Helene Wagner (2020). vegan: Community Ecology Package. R package version 2.5-7. https://CRAN.Rproject.org/package=vegan

Jeschke J, Gómez Aparicio L, Haider S, et al (2012) Support for major hypotheses in invasion biology is uneven and declining. NeoBiota 14:1-20. doi: 10.3897/neobiota.14.3435

Joshi J, Vrieling K (2005) The enemy release and EICA hypothesis revisited: Incorporating the fundamental difference between specialist and generalist herbivores. Ecol Lett 8:704-714. doi:

10.1111/j.1461-0248.2005.00769.x

Kariyat RR, Hardison SB, De Moraes CM, Mescher MC (2017) Plant spines deter herbivory by restricting caterpillar movement. Biol Lett 13: 20170176. doi: 10.1098/rsbl.2017.0176

Keane R, Crawley MJ (2002) Exotic plant invasions and the enemy release hypothesis. Trends Ecol Evol 17:164-170. doi: 10.1016/S0169-5347(02)02499-0

Page 14/ 25 
Koester RP, Skoneczka JA, Cary TR, et al (2014) Historical gains in soybean (Glycine max Merr.) seed yield are driven by linear increases in light interception, energy conversion, and partitioning efficiencies. J Exp Bot 65:3311-3321. doi: 10.1093/jxb/eru187

Lambert MG, Jung GA, Fletcher RH, et al (1989) Forage shrubs in North Island hill country 2. Sheep and goat preferences. New Zeal J Agric Res 32:485-490. doi: 10.1080/00288233.1989.10417921

Liao Z, Zhang R, Barclay GF, Feng Y (2013) Differences in competitive ability between plants from nonnative and native populations of a tropical invader relates to adaptive responses in abiotic and biotic Environments. PLoS One 8:e71767. doi: 10.1371/journal.pone.0071767

Liu H, Stiling P (2006) Testing the enemy release hypothesis: A review and meta-analysis. Biol Invasions 8:1535-1545. doi: 10.1007/s10530-005-5845-y

Lowe S, Browne M, Boudjelas S, De Poorter M (2000) 100 of the world's worst invasive alien species. A selection from the Global Invasive Species Database. The Invasive Species Specialist Group (ISSG) a specialist group of the Species Survival Commission (SSC) of the World Conservation Union (IUCN)

Lucas PW, Turner IM, Dominy NJ, Yamashita N (2000) Mechanical defences to herbivory. Ann Bot 86:913-920. doi: 10.1006/anbo.2000.1261

Lundberg P, Åström M (1990) Low nutritive quality as a defense against optimally foraging herbivores. Am Nat 135:547-562. doi: 10.1086/285061

Mediavilla S, Babiano J, Martínez-Ortega M, Escudero A (2018) Ontogenetic changes in anti-herbivore defensive traits in leaves of four Mediterranean co-occurring Quercus species. Ecol Res 33:1093-1102. doi: 10.1007/s11284-018-1622-0

Milewski A V, Young TP, Madden D (1991) Thorns as induced defenses: experimental evidence. Oecologia 86:70-75. doi: 10.1007/BF00317391

Mitchell CE, Agrawal AA, Bever JD, et al (2006) Biotic interactions and plant invasions. Ecol Lett 9:726740. doi: 10.1111/j.1461-0248.2006.00908.x

Montti L, Ayup MM, Aragón R, et al (2016) Herbivory and the success of Ligustrum lucidum: Evidence from a comparison between native and novel ranges. Aust J Bot 64:181-192. doi: 10.1071/BT15232

Muñóz E (2009) El espinillo (Ulex europaeus L. 1753) un invasor biológico en el sur de chile: estado de su conocimiento y alternativas de control. Gestión Ambient 17:23-44

Musariri T, Pegg N, Muvengwi J, Muzama F (2018) Differing patterns of plant spinescence affect blue duiker (Bovidae: Philantomba monticola) browsing behavior and intake rates. Ecol Evol 8:11754-11762. doi: 10.1002/ece3.4627 
Obeso JR (1997) The induction of spinescence in European holly leaves by browsing ungulates. Plant Ecol 129:149-156. doi: 10.1023/A:1009767931817

Oduor AMO, Gómez JM, Strauss SY (2010) Exotic vertebrate and invertebrate herbivores differ in their impacts on native and exotic plants: A meta-analysis. Biol Invasions 12:407-419. doi: 10.1007/s10530009-9622-1

Parker JD, Burkepile DE, Hayt ME (2006) Opposing effects of native and exotic herbivores on plant invasions. Science 311:1459-1461. doi: 10.1126/science.1121407

Pérez-Harguindeguy N, Díaz S, Garnier E, et al (2013) New handbook for standardised measurement of plant functional traits worldwide. Aust J Bot 61:167-234. doi: 10.1071/BT12225

Poorter H, De Jong R (1999) A comparison of specific leaf area, chemical composition and leaf construction costs of field plants from 15 habitats differing in productivity. New Phytol 143:163-176. doi: 10.1046/j.1469-8137.1999.00428.x

Popay I, Field R (1996) Grazing animals as weed control agents. Weed Technol 10:217-231. doi: $10.1017 /$ S0890037X00045942

Putman RJ, Pratt RM, Ekins JR, Edwards PJ (1987) Food and feeding behaviour of cattle and ponies in the New Forest, Hampshire. J Appl Ecol 24:369. doi: 10.2307/2403881

R Core Team (2017) R: A Language and Environment for Statistical Computing. https://www.Rproject.org/

Radcliffe JE (1985) Grazing management of goats and sheep for gorse control. New Zeal J Exp Agric 13:181-190. doi: 10.1080/03015521.1985.10426078

Radcliffe JE (1986) Gorse - A resource for goats? New Zeal J Exp Agric 14:399-410. doi: 10.1080/03015521.1986.10423056

Rafferty C, Lamont BB, Hanley ME (2005) Selective feeding by kangaroos (Macropus fuliginosus) on seedlings of Hakea species: effects of chemical and physical defences. Plant Ecol 177:201-208. doi: $10.1007 / \mathrm{s} 11258-005-2362-0$

Read J, Stokes A (2006) Plant biomechanics in an ecological context. Am J Bot 93:1546-1565. doi: 10.3732/ajb.93.10.1546

Reyes O, Casal M, Rego FC (2009) Resprouting ability of six Atlantic shrub species. Folia Geobot 44:1929. doi: $10.1007 / s 12224-009-9029-x$

Ridenour WM, Vivanco JM, Feng Y, et al (2008) No evidence for trade-offs: Centaurea plants from America are better competitors and defenders. Ecol Monogr 78:369-386. doi: 10.1890/06-1926.1 
Sanson G (2006) The biomechanics of browsing and grazing. Am J Bot 93:1531-1545. doi: 10.3732/ajb.93.10.1531

Shah DU, Reynolds TPS, Ramage MH (2017) The strength of plants: Theory and experimental methods to measure the mechanical properties of stems. J Exp Bot 68:4497-4516. doi: 10.1093/jxb/erx245

Speck T, Burgert (2011) Plant stems: Functional design and mechanics. Annu Rev Mater Res 41:169193. doi: 10.1146/annurev-matsci-062910-100425

Stokes KE, Bullock JM, Watkinson AR (2003) Ulex gallii Planch. and Ulex minor Roth. J Ecol 91:11061124. doi: 10.1046/j.1365-2745.2003.00836.x

Turner IM (1994) Sclerophylly: Primarily Protective? Funct Ecol 8:669. doi: 10.2307/2390225

Valladares F, Saldaña A, Gianoli E (2012) Costs versus risks: architectural changes with changing light quantity and quality in saplings of temperate rainforest trees of different shade tolerance. Austral Ecol 37:35-43. doi: 10.1111/j.1442-9993.2011.02245.x

Van Gelder HA, Poorter L, Sterck FJ (2006) Wood mechanics, allometry, and life-history variation in a tropical rain forest tree community. New Phytol 171:367-378. doi: 10.1111/j.1469-8137.2006.01757.x

Vázquez DP (2002) Multiple effects of introduced mammalian herbivores in a temperate forest. Biol Invasions 4:175-191. doi: 10.1023/A:1020522923905

Weraduwage SM, Chen J, Anozie FC, et al (2015) The relationship between leaf area growth and biomass accumulation in Arabidopsis thaliana. Front Plant Sci 6:167. doi: 10.3389/fpls.2015.00167

Wigley BJ, Coetsee C, Augustine DJ, et al (2019) A thorny issue: woody plant defence and growth in an East African savanna. J Ecol 107:1839-1851. doi: 10.1111/1365-2745.13140

Xu L, Freitas SMA, Yu FH, et al (2013) Effects of trampling on morphological and mechanical traits of dryland shrub species do not depend on water availability. PLoS One 8:1-8. doi:

10.1371/journal.pone.0053021

Zeileis A, Kleiber C, Jackman S (2008) Regression models for count data in R. J Stat Softw 27:1-25. doi: 10.18637/jss.v027.i08

Zhang Z, Pan X, Blumenthal D, et al (2018) Contrasting effects of specialist and generalist herbivores on resistance evolution in invasive plants. Ecology 99:866-875. doi: 10.1002/ecy.2155

Zuur AF, Leno EN, Walker N, Saveliev AA, Smith GM (2009) Mixed effects models and extensions in Ecology with R. Springer.

\section{Tables}


Table 1. Linear Mixed Models assessing the effects of range (fixed factor) on branch lengthstandardized thorn length $(\mathrm{L}, \mathrm{cm})$ and thorn width $(\mathrm{W}, \mathrm{mm}), \mathrm{L}: \mathrm{W}$ ratio, thorn density (number of thorns per cm of branch segment) and thorn biomass allocation (thorn:branch segment mass ratio) in adult plants of Ulex europaeus from the invaded and the native range. Population was entered as random factor.

\begin{tabular}{lcc}
\hline & $F(d f=1)$ & $\mathrm{P}$ \\
\hline Thorn length $(L)$ & 54.04 & $<\mathbf{0 . 0 0 0 1}$ \\
\hline Thorn width $(W)$ & 11.72 & $\mathbf{0 . 0 0 1 1}$ \\
\hline L:W & 35.40 & $\mathbf{< 0 . 0 0 0 1}$ \\
\hline Thorn biomass allocation & 19.13 & $\mathbf{< 0 . 0 0 0 1}$ \\
\hline Thorn density & 1.21 & 0.3334 \\
\hline
\end{tabular}

Table 2. Linear Mixed Models assessing the effect of range (invaded vs. native, fixed factor), branch length (covariate) and their interaction on thorn length (L, cm), thorn width (W, $\mathrm{mm}$ ), L:W ratio, thorn density (number of thorns per $\mathrm{cm}$ of branch segment) and thorn biomass allocation (thorn:branch segment mass ratio) in Ulex europaeus. Population was entered as random factor.

\begin{tabular}{l|ccccccc}
\hline \multicolumn{2}{c}{ Range $(R)$} & \multicolumn{2}{c}{ Branch length $(B L)$} & \multicolumn{2}{c}{$R \times B L$} \\
\hline \multirow{2}{*}{ Thorn length $(L)$} & $\mathrm{F}(d f=1)$ & $P$ & $\mathrm{~F}(d f=1)$ & $P$ & $\mathrm{~F}(d f=1)$ & $P$ \\
\hline \multirow{2}{*}{ Thorn width $(W)$} & 10.46 & $\mathbf{0 . 0 0 2 3}$ & 22.63 & $<\mathbf{0 . 0 0 0 1}$ & 1.12 & 0.2946 \\
L:W & 3.67 & 0.0618 & 3.02 & 0.0882 & 1.07 & 0.3062 \\
\cline { 2 - 8 } Thorn density & 5.63 & $\mathbf{0 . 0 2 1 3}$ & 14.40 & $\mathbf{0 . 0 0 0 4}$ & 0.19 & 0.6647 \\
\cline { 2 - 8 } Thorn biomass allocation & 3.17 & 0.0818 & 24.43 & $<\mathbf{0 . 0 0 0 1}$ & 5.43 & $\mathbf{0 . 0 2 3 5}$ \\
\cline { 2 - 8 } & 12.19 & $\mathbf{0 . 0 0 0 9}$ & 4.13 & $\mathbf{0 . 0 4 6 7}$ & 5.79 & $\mathbf{0 . 0 1 9 3}$ \\
\hline
\end{tabular}

Table 3. Content (\%) of lignin, acid detergent fiber (ADF), neutral detergent fiber (NDF), cellulose and dry matter digestibility (DMD) in $U$. europaeus thorns from the invaded (Chile) and the native range (Spain). Results of the Linear Mixed Models (LMM) assessing 
the effect of range (invaded vs. native) as fixed factor are also shown. Population was entered as random factor.

\begin{tabular}{l|ccrc}
\hline \multicolumn{2}{c}{ Mean $\pm S E$} & \multicolumn{2}{c}{$L M M$} \\
\hline \multirow{2}{*}{ Lignin } & Invaded range & Native range & F & $P$ \\
ADF & $16.2 \pm 1.9$ & $21.7 \pm 2.1$ & 2.10 & 0.2236 \\
NDF & $34.6 \pm 3.4$ & $45.1 \pm 1.4$ & 7.35 & 0.0543 \\
Cellulose & $45.5 \pm 2.2$ & $58.8 \pm 1.9$ & 10.70 & $\mathbf{0 . 0 2 9 1}$ \\
DMD & $28.9 \pm 2.6$ & $46.7 \pm 2.3$ & 16.99 & $\mathbf{0 . 0 1 3 1}$ \\
\cline { 2 - 5 } & $47.0 \pm 2.1$ & $38.3 \pm 2.0$ & 3.34 & 0.1384 \\
\hline
\end{tabular}

Figures 
A)

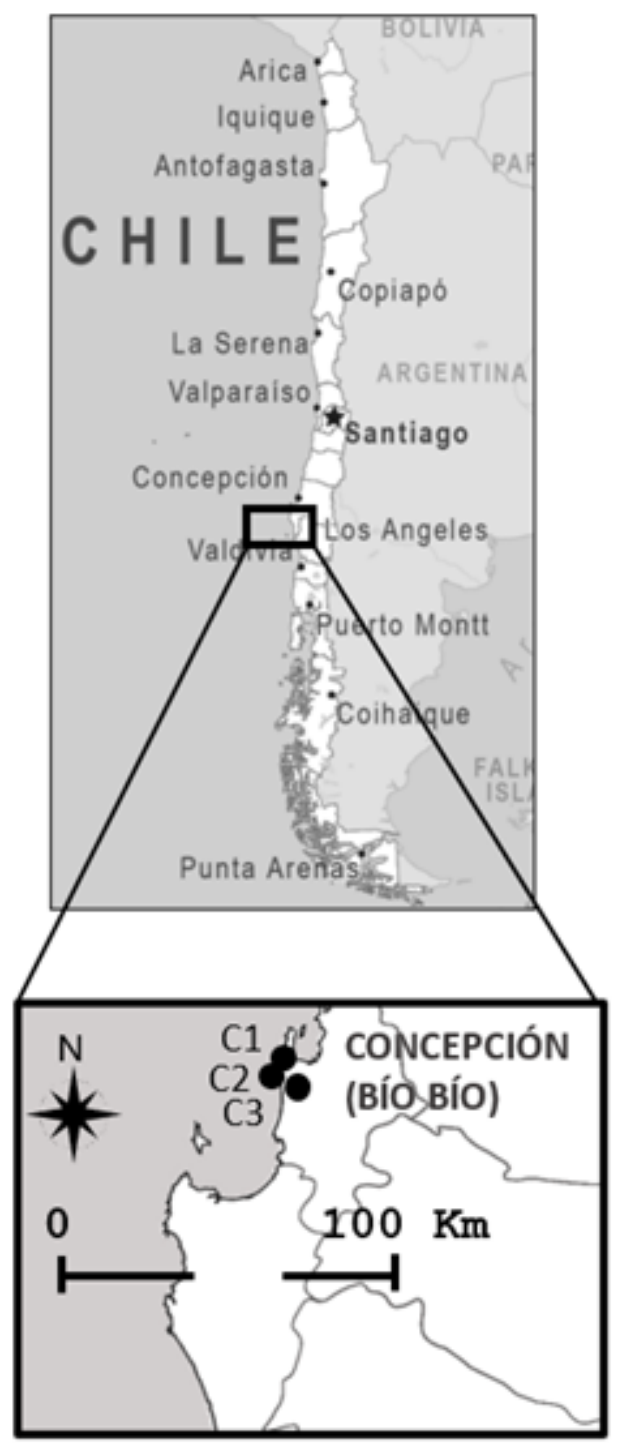

B)

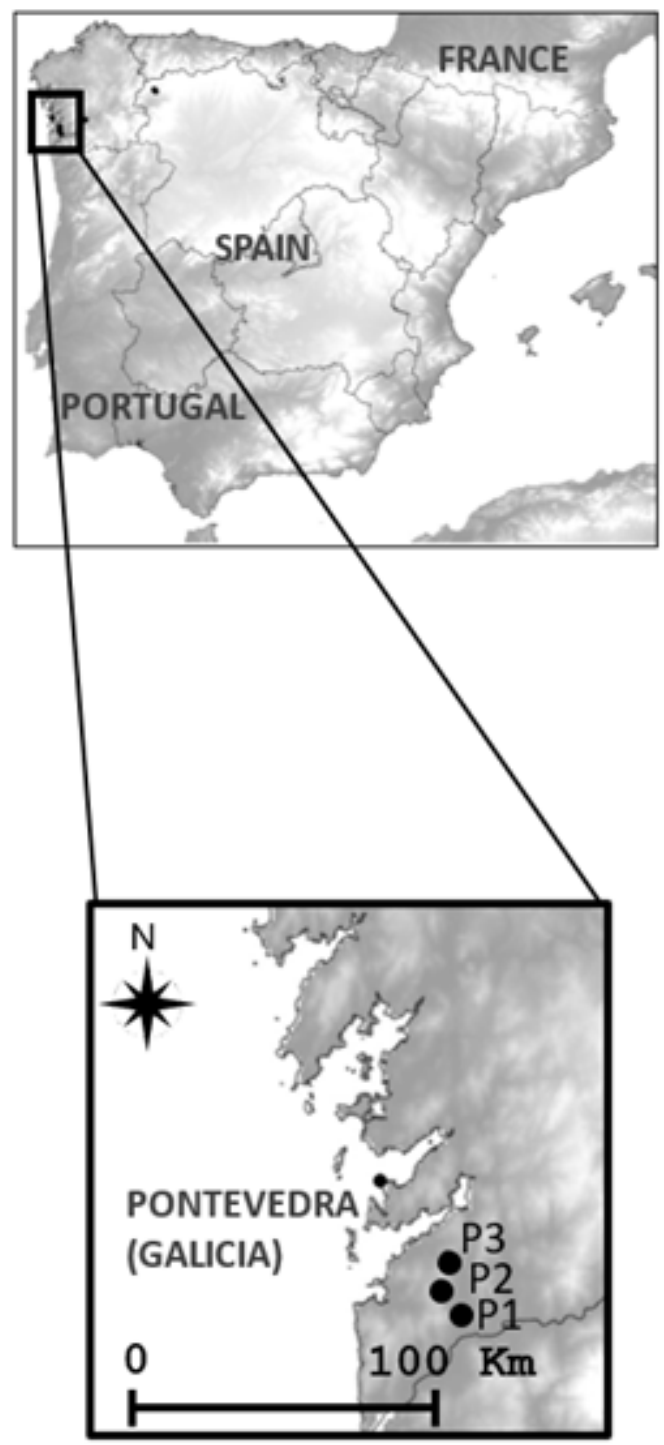

\section{Figure 1}

Location of the study sites: A) Concepción (Bío Bío, Chile) and B) Pontevedra, (Galicia, Spain), invaded and native distribution ranges of Ulex europaeus, respectively. In each site, three $U$. europaeus populations were selected for sampling: C1-C3 in Concepción (Chile) and P1-P3 in Pontevedra (Spain).

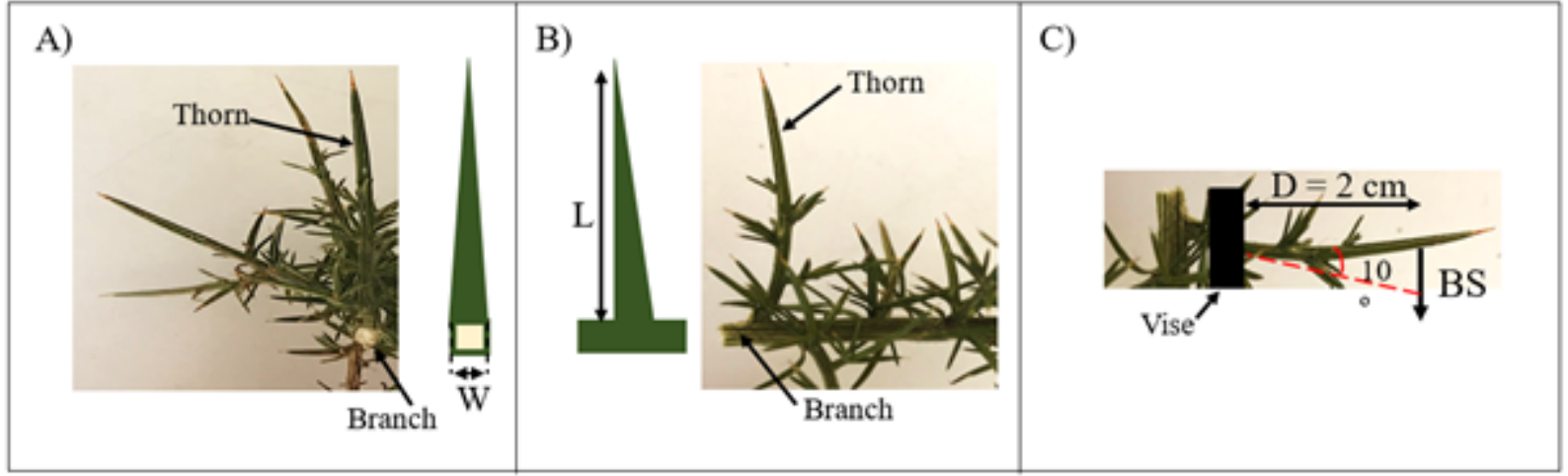




\section{Figure 2}

Proximal (A) and lateral (B) view of a branch segment of Ulex europaeus (picture) complemented with a basic scheme of a single thorn showing some spinescence traits measured: thorn length $(L)$ and, thorn base width perpendicular to the branch (W). Scheme showing the bending test applied to the thorns (C). D: the displacement from the vise to the point where the weight is applied in the bending test; BS: bending strength (flexural resistance, see text for additional details).
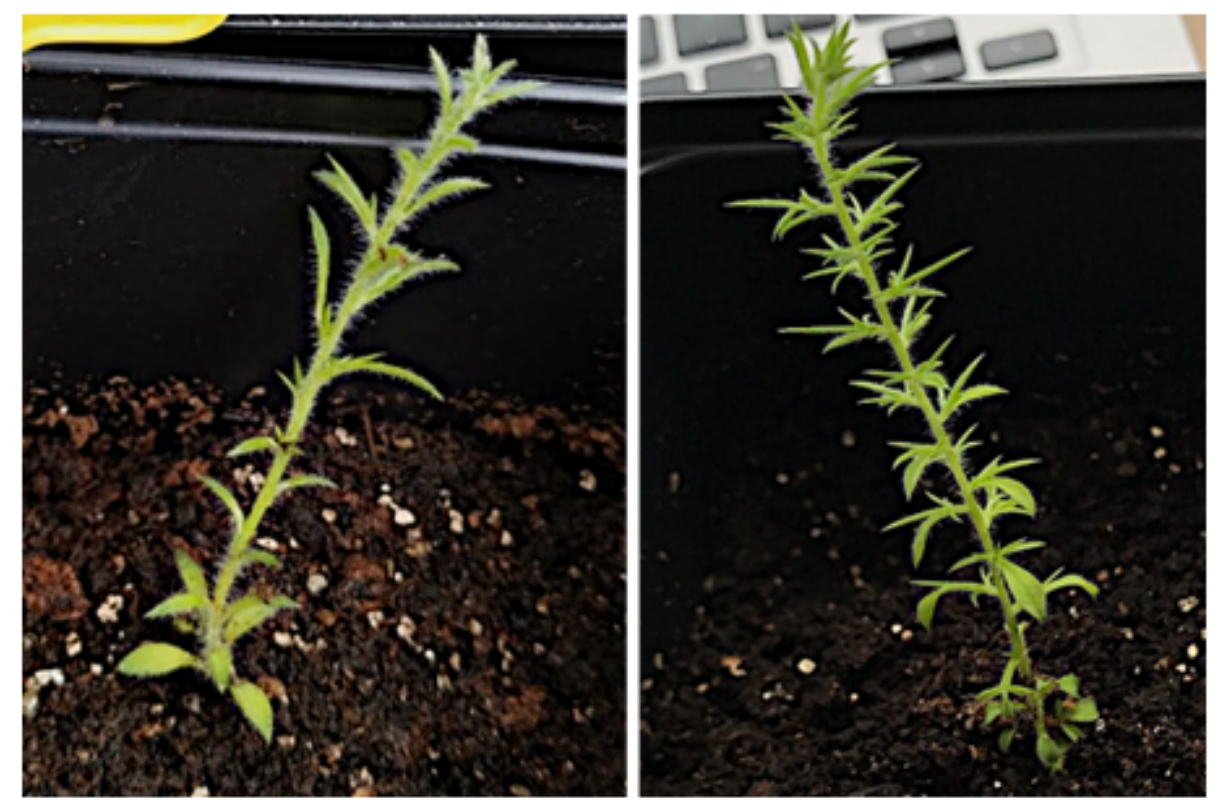

\section{Figure 3}

Seedlings of U. europaeus from the invaded (Chile, left panel) and the native range (Spain, right). Note that the seedling from Spain developed more spines than that from Chile. 

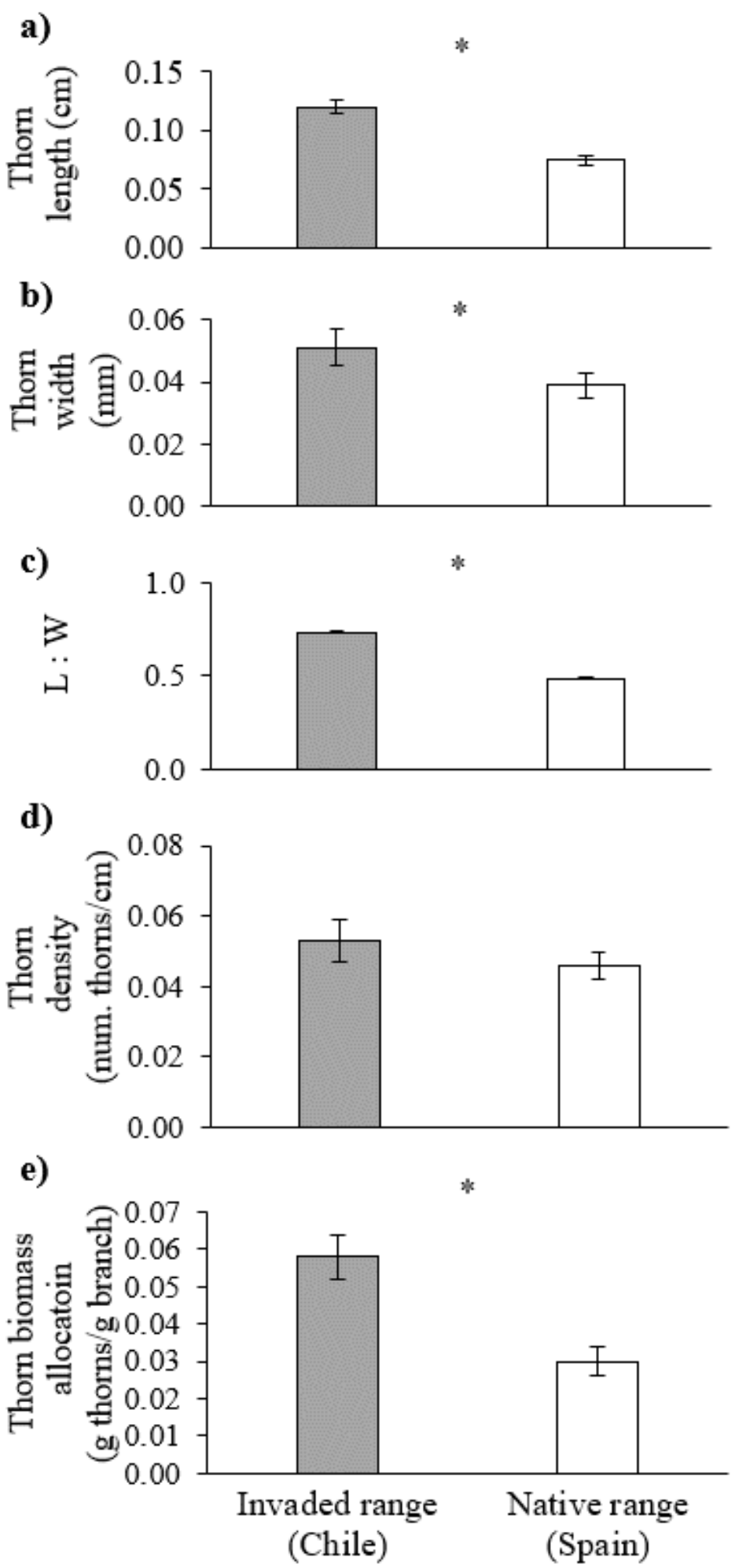

\section{Figure 4}

Mean ( \pm SE) of branch length-standardized spinescence variables: a) thorn length (L), b) thorn width (W), c) $L: W, d)$ thorn density and e) thorn biomass allocation, in Ulex europaeus from the invaded and native range (Chile and Spain, respectively). Asterisks indicate significant differences between ranges after a Linear Mixed Model (population as random factor) for each variable. 

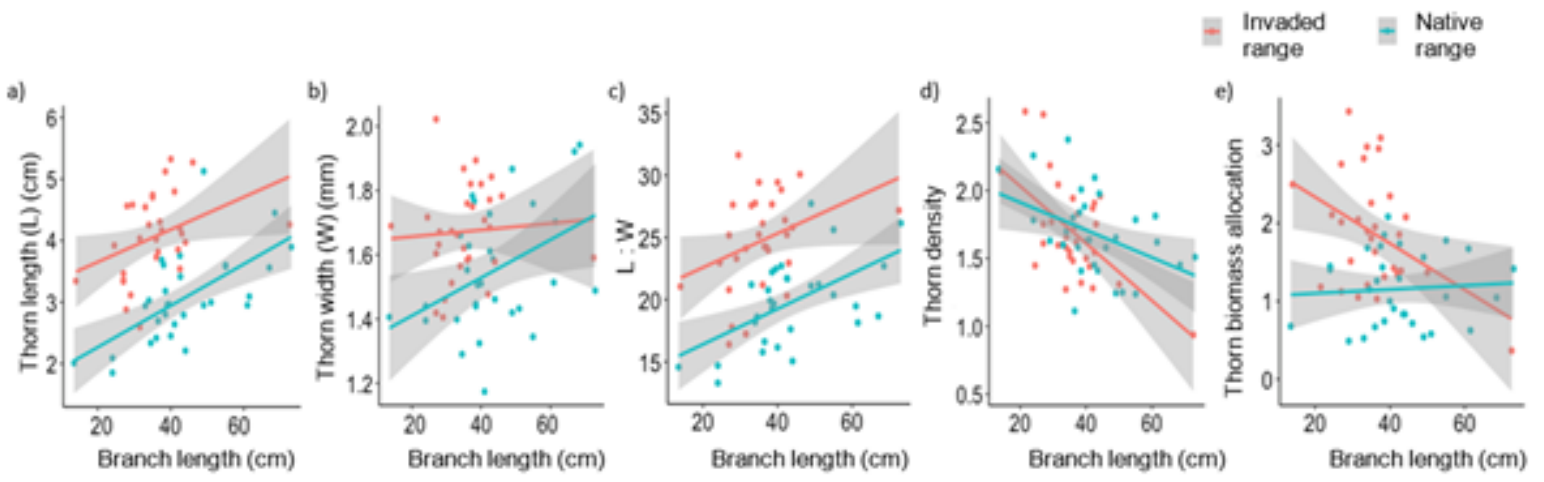

\section{Figure 5}

Linear regression of a) thorn length $(L)(\mathrm{cm}), b)$ thorn width $(W)(\mathrm{mm}), \mathrm{c}) \mathrm{L}: W$ (thorn slenderness), d) thorn density and e) thorn biomass allocation as a function of branch length $(\mathrm{cm})$ in Ulex europaeus individuals from the invaded and native ranges (Chile and Spain, respectively). Statistical results in Table 2.

\section{Range $\approx$ Invaded $\leftarrow$ Native}

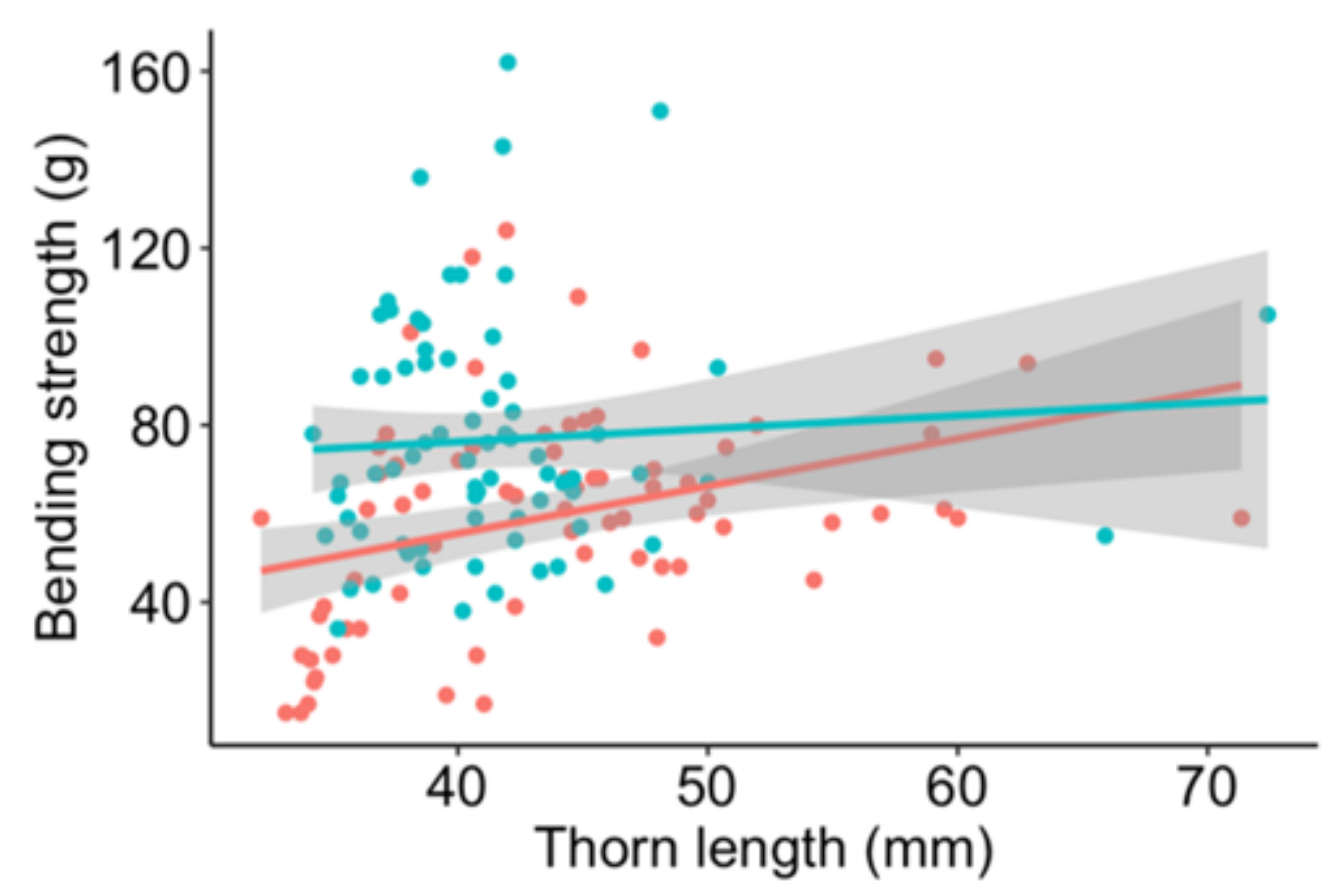

Figure 6

Linear regression for bending strength as a function of thorn length in Ulex europaeus from invaded and native ranges (Chile and Spain, respectively). Bending strength was significantly influenced by Range, Thorn length and their interaction (statistical results in the text). 
a)

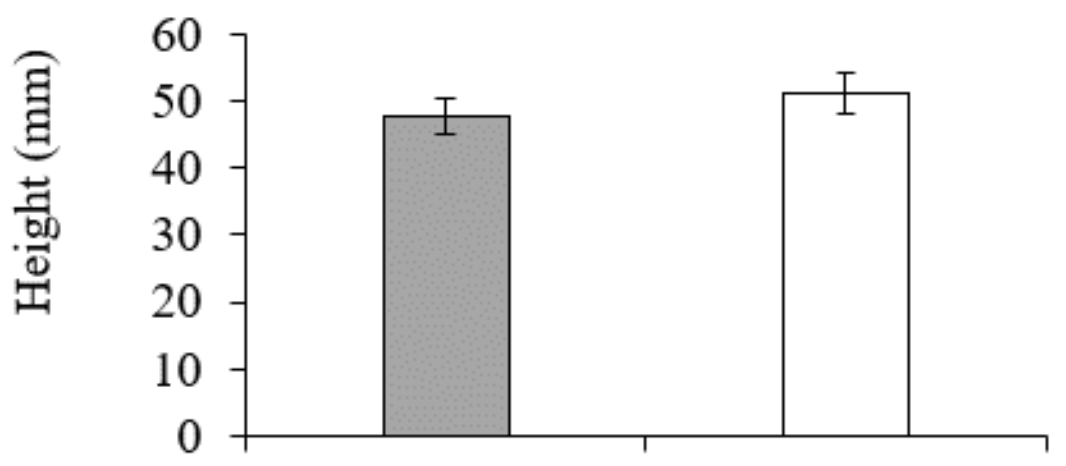

b)

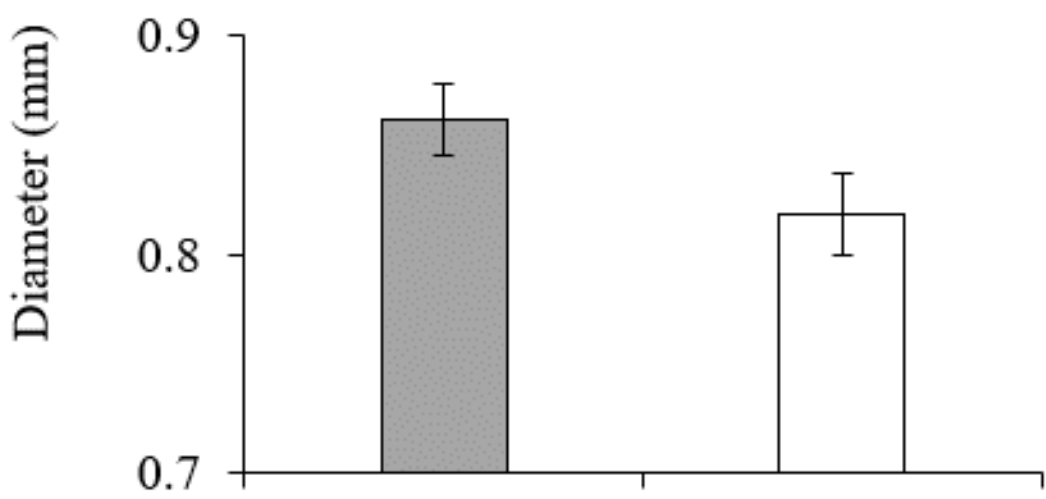

c)

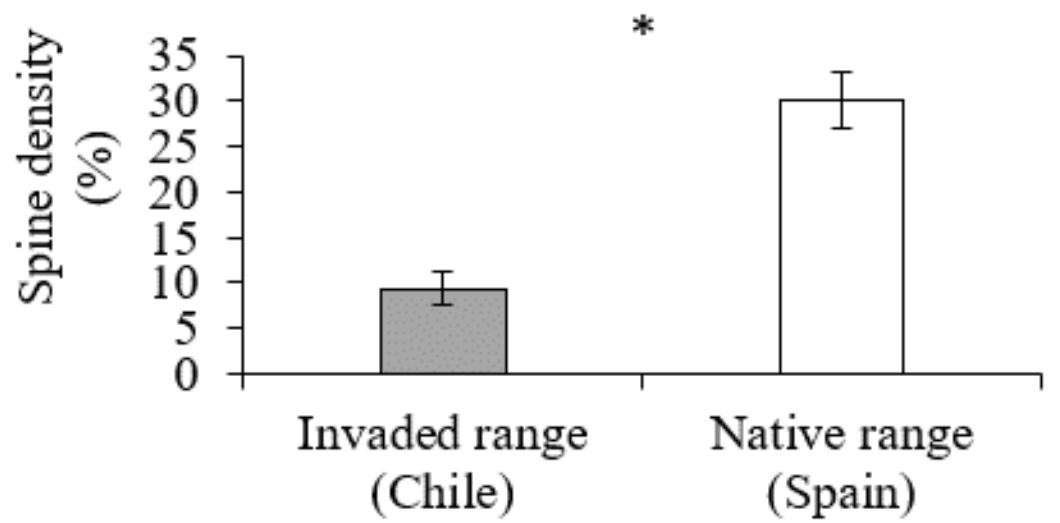

Figure 7

Mean ( \pm SE, $n=120$ ) of the variables: a) height $(\mathrm{mm}), b)$ stem diameter $(\mathrm{mm})$ and $\mathrm{c}$ ) spine density $(\%)$ of Ulex europaeus seedlings from the invaded and the native range (Chile and Spain, respectively). Asterisks indicate significant differences between ranges after a linear mixed model (population as random factor) for each variable. 


\section{Supplementary Files}

This is a list of supplementary files associated with this preprint. Click to download.

- Onlineresource1.docx

- Onlineresource2.docx

- Onlineresource3.docx 